\title{
There is plenty of room at the bottom for small linguistic stuff
}

\author{
Norbert Corver \\ Utrecht Institute of Linguistics-OTS, Utrecht University, The Netherlands \\ E-mail: N.F.M.Corver@uu.nl
}

\begin{abstract}
This article is concerned with the possibility that syntactic structure may feature "small stuff" not just at the very top of the clause, but also lower down, in the domain that would usually be regarded as the lexical domain. The analysis is based on a range of (dialectal) Dutch and Frisian data, suggesting an initial analysis for the relevant morphosyntactic facts in terms of which a "smaller" higher category - what superficially looks like the definite and indefinite article in the relevant systems - seems to be located at the bottom of a nominal structure.
\end{abstract}

Keywords: function word, article, root, extended projection, categorial identity hypothesis

\section{Introduction ${ }^{1}$}

"Don't sweat the small stuff!" People sometimes hear this idiomatic expression when they worry too much about small things in life that cause concern. Rather than getting mired down in the details, one should focus on the big picture and the large goals. In his popular book Don't sweat the small stuff . . a and it's all small stuff, the psychotherapist Richard Carlson (1997) notes that "So many people spend so much of their life energy sweating the small stuff that they completely lose touch with the magic and beauty of life."

Although the above proverbial wisdom carries a lot of truth as regards normal daily life, many a scientist will adhere to the reverse proverbial wisdom when it concerns his/her life as a scientist: "Do sweat the small stuff!". That is, one should be concerned about the small things. A fine illustration of this scientific position is Richard Feynman's talk to the American Physical Society on December 29, 1959, at Caltech. In his talk, entitled There is Plenty of Room at the Bottom (Feynman 2007), the physicist emphasizes the importance of "the problem of manipulating and controlling things on a small scale." Furthermore, by "sweating the small stuff", the scientist gets in touch with the magic and beauty of life. Feynman has famously voiced the "beauty of small stuff" in his monologue known as "Ode to the flower"; italics by NC. ${ }^{2}$

\footnotetext{
${ }^{1}$ I would like to thank two anonymous reviewers for their useful comments on an earlier version of this article.

${ }^{2}$ For a nice animation: http://vimeo.com/55874553
} 
I have a friend who's an artist and has sometimes taken a view which I don't agree with very well. He'll hold up a flower and say "look how beautiful it is", and I'll agree. Then he says "I as an artist can see how beautiful this is but you as a scientist take this all apart and it becomes a dull thing", and I think that he's kind of nutty. First of all, the beauty that he sees is available to other people and to me too, I believe. Although I may not be quite as refined aesthetically as he is ... I can appreciate the beauty of a flower. At the same time, I see much more about the flower than he sees. I could imagine the cells in there, the complicated actions inside, which also have a beauty. I mean it's not just beauty at this dimension, at one centimeter; there's also beauty at smaller dimensions, the inner structure, also the processes. The fact that the colors in the flower evolved in order to attract insects to pollinate it is interesting; it means that insects can see the color. It adds a question: does this aesthetic sense also exist in the lower forms? Why is it aesthetic? All kinds of interesting questions which the science knowledge only adds to the excitement, the mystery and the awe of a flower. It only adds. I don't understand how it subtracts.

http://www.youtube.com/watch?v=ZbFM3rn4ldo

Beauty at smaller dimensions, the inner structure, is also available in the build of human language. A nice illustration comes from the grammatical behavior of functional categories in human language. Ever since the late 1980's, syntacticians have gained a much better understanding of the grammatical behavior of functional categories, the small stuff of syntax (see Corver 2013 for an overview). First of all, it has been shown that these "minor categories", just like the "major categories" (nouns, verbs, adjectives) fully participate in phrasal syntax, in the sense that they are not simply bare heads but rather elements that combine with other elements (complements, specifiers) and consequently form bigger (i.e., phrasal) units, as schematically represented in (1a); see e.g., Chomsky (1986), Abney (1987). Secondly, evidence has been provided in support of the idea that the syntactic projection of a lexical category - the so-called lexical projection - is structurally contained within the projection of a functional category; the so-called Functional Head Hypothesis, which is also represented by (1a); cf. Grimshaw (1991, 2005). Thirdly, it has been argued that the functional layers (e.g., TP and CP) and the lexical layer (e.g., VP), in spite of representing a "divided" syntactic structure, form an organizational unit; see Grimshaw's (1991) notion of Extended Projection. This unity resides in the fact that the lexical and functional heads of the extended projection are of the same categorial type (see also van Riemsdijk's (1998) Categorial identity hypothesis). For example, the lexical head $\mathrm{V}$ and the functional heads $\mathrm{T}$ and $\mathrm{C}$ share the property of being verbal. The verbal nature of the three heads accounts for the fact that verbs can move to higher functional heads such as $\mathrm{T}$ and $\mathrm{C}$, as familiar from V-to-T movement phenomena in Romance languages (Emonds 1978, Pollock 1989) and the well-known Verb Second phenomenon (movement of the finite verb to C) in Germanic languages (den Besten 1983). Another illustration of categorial identity within the extended projection comes from the N-to-D movement phenomenon in the extended nominal projection; see, for example, Longobardi's (1994) analysis of proper names in Italian, and Ritter's (1988) analysis of Construct state constructions in Modern Hebrew. The noun $(\mathrm{N})$ can use $\mathrm{D}$ as a landing site, since $\mathrm{N}$ and $\mathrm{D}$ share the (categorial) property of being nominal. In short, the categorial nature of the entire extended nominal projection is preserved.
a. [FP Spec [F' F [LP L ] ] ]

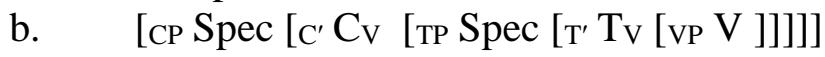


Clearly, functional categories, just like lexical ones, fully participate in syntax and are subject to organizational principles that contribute a certain beauty to the inner structure of an extended projection.

The above-mentioned head movement phenomena show that a lexical head $(\mathrm{V}, \mathrm{N})$ can end up in a higher functional head position in phrase structure. Thus big stuff (content words/lexical categories) can end up at the top of the tree as a result of head movement processes. According to the Categorial identity hypothesis, such processes are legitimate since the categorial nature of the entire extended projection is preserved. The question arises whether we also find the reverse situation: Do we ever find small stuff (function words/functional categories) at the bottom of the tree; i.e., in a position that is normally occupied by a lexical head or phrase? Under the Categorial identity hypothesis, one might expect to find such patterns, since the categorial nature of the extended nominal projection is preserved.

In what follows I will present and discuss some patterns from (varieties of) Dutch and Frisian which seem to support the hypothesis that small stuff (functional material) can be found also at the bottom of the tree (i.e., the extended projection). Evidence will come from pronominalization-like phenomena. Specifically, functional elements that correspond to indefinite and definite articles can be found at the bottom of an extended nominal projection.

I will start my discussion with two illustrations from the domain of possessive pronominals. Consider, first of all, the examples in (2) and (3) from Hindeloopen Frisian (de Boer 1950, Corver and van Koppen 2010, 2016) and Giethoorn Dutch, respectively.

Hindeloopen Frisian
a. mien aaite
b. mien tante
c. mien bon
d. mien bon

Giethoorn Dutch

a. mien opa

b. mien tante

c. mien kiend

d. mien kiender "my grandfather"

"my aunt"

"my child"

"my children"

In these examples, in which the possessive pronoun is used attributively, the (invariant) possessive pronoun mien is followed by a lexical noun.

Observe now that, in Hindeloopen Frisian, the invariant affix -en shows up right after the pronoun when the latter is used substantively; see (4a). As shown by (4b), Giethoorn Dutch exhibits the invariant affix -de right after the possessive pronoun.
a. mien-en
(Hindeloopen Frisian)
b. mien-de
(Giethoorn Dutch)

The -en-affix in (4a) has the same pronunciation as the indefinite article - namely /on/, as in /on bok/ "a book" - and the -de affix in (4b) has the same pronunciation as the definite article namely /də/, as in /də opa/ "the grandfather". In view of this surface parallelism with articles, one might hypothesize that articles can be used as pro-forms that substitute for the lexical noun $(\mathrm{N}(\mathrm{P}))$. Schematically:
a. [FP mien [NP -en[థ:_] ]
b. [FP mien [NP - $\left.\left.\mathrm{de}_{\left[\Phi: \_\right]}\right]\right]$ 
As indicated, I assume that these pro-forms are unspecified for number and gender, here represented as $[\Phi: \ldots]$. The element $-e n$, for example, can pronominalize both singular and plural nouns. In this respect, it differs from the indefinite article /ən/, which can only be used in combination with singular (count) nouns. ${ }^{3}$ The element $-d e$ also seems to be unspecified given the fact that it can replace a neuter noun ('t kiend "the neuter child").

If we are right in saying that/ən/ and /də/ are pro-nominalizing articles in (4), the question arises whether there are any other nominal constructions featuring article-like pro-forms. In what follows, I will point out a few constructions that one might want to analyze as patterns featuring an instance of the article pro-form at the "bottom" of the tree. Unfortunately, an in-depth analysis of these nominal constructions falls beyond the scope of this article. My main aim is to draw the reader's attention to a number of nominal patterns displaying small stuff (i.e. functional material) at the bottom of the tree.

I'll start my discussion with some patterns featuring -en (i.e. /ən/). Consider the following examples:

a. De trein vertrekt iets na enen liets voor tweeën.

the train leaves a.little after one-EN a.little before two-EN

"The train will leave a little before one o'clock/a little after two o'clock."

b. Jan reed iets naar achteren/voren.

Jan drove a.little to back-EN/ front-EN

"Jan drove a little backwards/forwards."

In (6a), -en attaches to a numeral and substitutes for the noun uur "hour": na één/twee uur, after one/two hour, "after one/two o'clock", In (6b), -en attaches to a locative preposition (achter/voor) and replaces the so-called Ground (see Talmy 2000) of the preposition; see also Pretorius (2017). If -en is an indefinite pro-form substituting for $\mathrm{N}(\mathrm{P})$, then the above patterns have the structures in $(7):^{4}$
a. [PP iets $\left[\mathrm{P}^{\prime}\right.$ voor $[\mathrm{NumP}$ twee $\left.\left.[\mathrm{NP}-\mathrm{en}]]\right]\right]$
b. $\quad$ [PP/DIR naar [PP/LOc achter [NP -en]]]

It should be noted that one also finds patterns in which the -en element is accompanied by the bound morpheme $-s$, which is traditionally identified as genitival case. Some examples are given in (8); (8a) is an example from Groningen Dutch (ter Laan 1953: 122).

$\begin{array}{lllll}\text { a. I } & \text { zee 't } & \text { oet } & \text { gekk-en-s } \\ & \text { I said it } & \text { out.of } & \text { crazy-EN-S } \\ & \text { "I said it for fun." } & & \end{array}$

\footnotetext{
${ }^{3}$ As noted in Bennis, Corver and den Dikken (1998), the Dutch indefinite article een sometimes shows up before a noun whch is not of the right sort. For example, een can precede a proper name, which has a definite interpretation, in so-called $N$-van- $N$-constructions (die etter van een Jan, "that jerk of a Jan"). Also, een can precede a plural noun in exclamative noun phrases such as wat een boeken! (what a books, "how many books!"). Bennis et al. call this een a "spurious indefinite article". They take it to be unspecified for number.

${ }^{4}$ The Dutch "adverb" gisteren features the element -en at the end. The English counterpart yesterday (yester+day) hints at an analysis according to which Dutch -en is the equivalent of English day.
} 


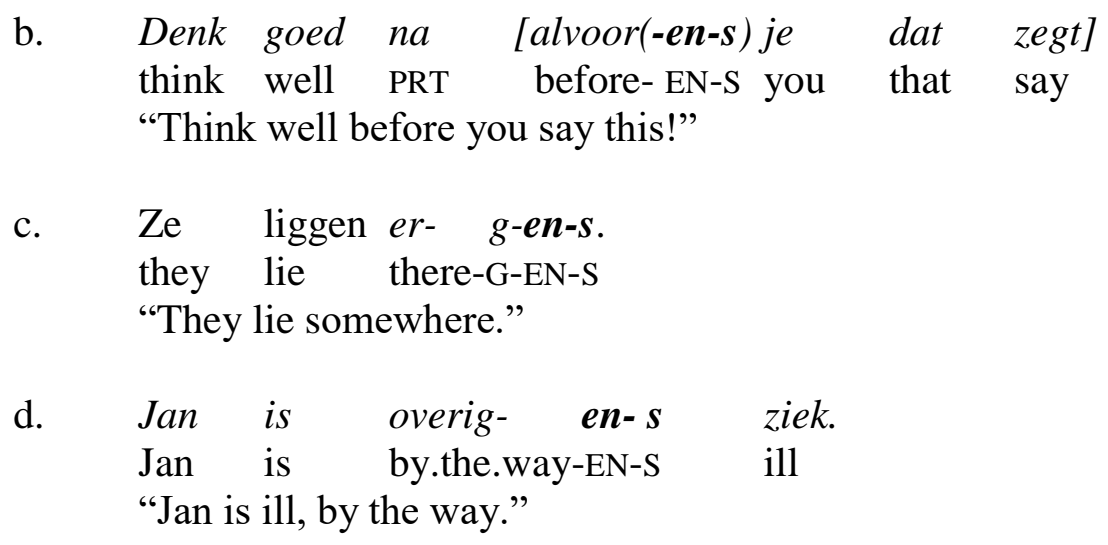

It is tempting to analyze the -en morpheme as an indefinite pro-nominal element. In (8a), -en fulfills the same role as English -ness, as in craziness, or Dutch -heid, as in gekheid. In (8b), en seems to function as the complement of the prepositional element voor and to represent "time/moment" (i.e. "before the time/moment at which you will say that"). In (8c), -en is part of an (indefinite) locative "adverbial expression" featuring the locative adverb er. Possibly, the indefinite -en represents a non-specific ground, while er provides the locative information. In (8d), finally, the "adverbial" expression overigens contains the element -en. The element overig is an adjectival constituent, as is clear from expressions like de overige deelnemers "the other participants". It does not seem implausible to analyze overig in (8d) as an attributive modifier of the indefinite pronominal -en, where -en is a pro-form that stands for "way", as also suggested by the English translation "by the way".

The question, obviously, arises what kind of element $-s$ is. In the spirit of Emonds (1985) and Pesetsky (2013) I assume that $-s$, traditionally analyzed as a genitival case suffix, is a categorial suffix (i.e., a part-of-speech-suffix). Specifically, $-s$ is an affixal realization of the noun; see also Corver (to appear). In a way, $-s$ marks the nouniness of the element to which it is attached (in casu: -en). This brings us to the following (tentative) analyses of the patterns in (8):
a. [PP oet [FP gek [NP-en+s]]]
b. [CP [PP al [P, voor [NP -en+s]]] [C, C [TP je dat zegt $]]]$
c. $[\mathrm{pP}$ er $[\mathrm{P},-\mathrm{g}[\mathrm{NP}-\mathrm{en}+\mathrm{s}]]]$
d. [FP overig [NP - en $+\mathrm{s}]]$

Under an analysis in which NP is decomposed into a root $(\sqrt{ })$ and a categorial node $\left(\mathrm{n}^{0}\right)$, as in Borer (2005) and Marantz (1997), one might reinterpret the NP-part in (9) as follows: $-s$ is an affixal realization of $\mathrm{n}^{\circ}$ and -en is a pro-form that occupies the root-position. The sequence $e n+s$ would then be derived by moving (and adjoining) the root to the categorial node. This analysis is exemplified in (10a) for the pattern oet gekkens in (9a):

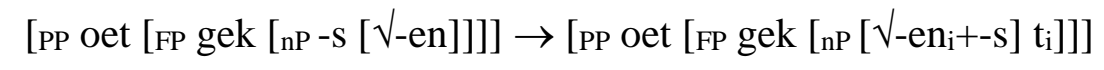

Of course, this analysis raises the question as to what allows the appearance of a functional element like -en as a root. Normally, roots (e.g., car, fish, bike) represent conceptually rich objects. Clearly, -en does not have this rich meaning. At the end of this article, I will come back to this issue. 
Let me finish this brief discussion about -en with the patterns in (11); examples $(11 \mathrm{~b}, \mathrm{c})$ are drawn from Royen (1947-1954: 180) and represent colloquial/dialectal varieties of Dutch. (11a) is the Standard Dutch form.

$\begin{array}{lll}\text { a. Ineens } & \text { was het stil. } \\ \text { in-one-S was it } & \text { quiet } \\ \text { "All at once it was silent." } & \end{array}$

b. Wat had haar nu ineenen
what had her now at-one-EN into a
"What turned her into a mad woman?"

c. In een-s-en was het weg en nergens $\begin{aligned} & \text { meer } \\ & \text { in } \\ & \text { one-S-EN was it away and nowhere } \\ & \text { te vinden. }\end{aligned}$
to find
"All of a sudden it had gone, and it was impossible to find."

I propose that the adverbial expression ineens has a composite structure, consisting of the following overtly realized elements: the preposition in, the numeral één "one", and the element $-s$, which I take to be a suffixal realization of $\mathrm{n}^{0}$. As shown in (12), I take the root node to be phonetically empty in Standard Dutch.

$$
\text { [PP in [NumP een }[\mathrm{nP}-\mathrm{s}[\sqrt{\varnothing}]]]
$$

The patterns in (11b) and (11c) are minimally different from the one in (11a). As opposed to (11a), they have the pro-form -en in the root position:

$$
\begin{array}{ll}
\text { a. } & {\left[\mathrm{pP} \text { in }\left[\text { NumP een }\left[\mathrm{nP}^{\mathrm{o}}[\sqrt{ } \text {-en }]\right]\right]\right]} \\
\text { b. } & {\left[\mathrm{pP} \text { in }\left[\text { NumP een }\left[\mathrm{nP}^{\mathrm{o}}(=-\mathrm{s})[\sqrt{ } \text {-en }]\right]\right]\right]}
\end{array}
$$

In (13b), the categorial node remains phonetically empty, while in (13b) it is occupied by the affixal element $-s$.

Having briefly discussed some patterns featuring the indefinite pro-form -en (/ən/), let us now turn to patterns that display the definite pro-form - $d e$. I would like to propose that a demonstrative-like element such as hetzelfde "the same" (see (14a)) and an ordinal such as zesde "sixth" (see (14b)) have a composite structure (see (15)). ${ }^{5}$

Marie gedroeg zich vreemd en Kees gedroeg
Marie behaved REFL strangely and Kees behaved
zich hetzelfde.
REFL the ${ }_{\text {neut }}+$ same+the
"Marie behaved strangely and Kees behaved in the same way."

\footnotetext{
${ }^{5}$ See also Emonds (1985) for the claim that -th in ordinals such as fourth, sixth etc., is a suffixal realization of the definite article.
} 


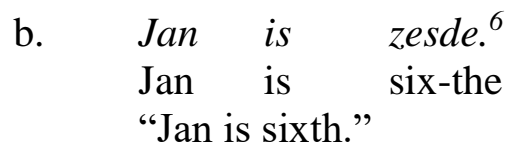

(15) a. [DP het [FP zelf $\left.\left[\mathrm{F}^{\prime} \mathrm{F}[\mathrm{NP}-\mathrm{de}]\right]\right]$

b. [NumP Zes [NP - de]]

I take the pro-form -de in (15a) to represent the abstract meaning "manner/way", as is also suggested by its English counterpart: John behaved the same (way). In (15b), -de possibly constitutes the definite-pronominal counterpart of the first noun (nummer, stoel) in expressions such as (16):

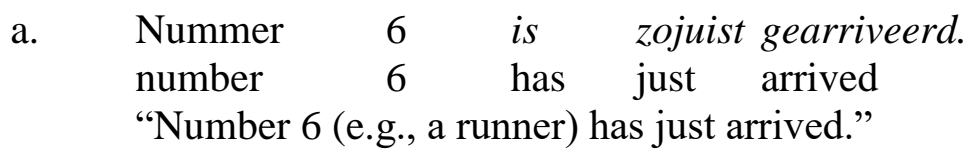

b. Jan zat op stoel 2.
Jan sat on chair 2
"Jan sat on chair number two."

The obligatory absence of the definite article in (16) gives these nominal expressions a Construct-State-like flavor. In the spirit of Ritter's (1988) N-to-D movement analysis of Hebrew Constuct State constructions, one might analyze the pattern stoel 2 as in (17a); see also de Belder (2009). The ordinal zesde would have the same base structure, the only difference being that the pro-form -de remains in situ (i.e. does not move to $\mathrm{D}$ ), as in (17b):
a. $\quad\left[\mathrm{PP}\right.$ op [DP stoel $\left[\mathrm{NumP}\right.$ twee $\left.\left.\left.\left[\mathrm{NP} \mathrm{t}_{\mathrm{i}}\right]\right]\right]\right]$
b. [NumP Zes [NP -de]]

Interestingly, we find ordinals and variants of hetzelfde that feature the element $-s:^{7}$
a. $\quad t$ - selaf-s-te
the-same-S-TE
"the same"
b. Jan werd negen-s-te
Jan became nine- S-TE
"Jan became ninth."

(Aarschot Dutch; Pauwels 1958)

\footnotetext{
${ }^{6}$ Ordinals such as zesde can also be used attributively, as in de zesde symfonie van Beethoven "the sixth symphony by Beethoven". Under the phrasal analysis of zesde in (17b), ordinals occupy a specifier position within the extended nominal projection, rather than a head position on the nominal projection line.

${ }^{7}$ I take -te to be the same element as - de, the only difference being the voicelessness of the dental consonant. Note that we also find definite articles featuring a voiceless dental consonant in expressive phrases such as Te drommel! (the deuce, "damned!"). Another occurrence of -te which possibly has a relationship with the definite pro-form $d e$ is -te in expressions such as diep-te "depth", hoog-te "height", ver-te "far distance", breed-te "width". Notice that some of the English translations also feature the article-like suffix -th at the end.

${ }^{8}$ Standard Dutch uses the form negen-de for "ninth". Notice, though, that the sequence -ste is attested in forms such as acht-s-te "eighth" and twintig-s-te "twentieth".
} 
Under an analysis in which NP is decomposed into the structure $[\mathrm{nP} \mathrm{n}[\sqrt{ }]]$, the patterns in (18) can be assigned the structures in (19): ${ }^{9}$
a. [DP t [FP seləf [F, F [nP $-\mathrm{s}[\sqrt{ }$-te $]]]]$
b. [NumP negen $[\mathrm{nP}-\mathrm{s}[\mathrm{V}$-te $]]]$

Another nominal construction which displays the use of a definite article as a noun phrase internal pro-form is given in (20), which is from child Dutch; see van Kampen and Corver (2006):
$\begin{array}{llll}\text { a. En } & \text { achterop } & \text { staat } & \text { Laura- s-te } \\ \text { and } & \text { at-the-back } & \text { stands Laura-s-TE }\end{array}$
(S. 4,5 years)
"And at the back stands Laura's (= Laura's drawing)."
b. En als het opa- s- te is?
(S. 4,5 years)
"And what if it is grandpa's (= grandpa's glasses)?"

The patterns Laura-s-te "Laura's" and opa-s-te "grandpa's" have the element -te at the end of the possessive noun phrase. I propose that -te is a definite pro-form that pronominalizes the possessum-part of the noun phrase. The $-s$ in between Laura/opa and -te is the possessive marker that is attached to the proper name/kinship noun, as in Laura's/opa's fiets "Laura's/grandpa's bike". Schematically:

$$
\text { [PosP Laura's [nP n }[\sqrt{ } \text {-te }]]]
$$

The pattern in (21) leads us to another, arguably related, possessive construction, namely the one in (22) from Oerle Dutch, a southern Dutch variety; see de Bont (1958: 385-86):

$$
\begin{array}{lllllll}
\text { a. } & r \quad \text { Hoor wordt nät zeu grijs a's de } & \text { Nätjes. } \\
\text { her hairs gets just as grey as } & \text { the } & \text { Netje's } \\
\text { "Her hair is getting as grey as Netje's." } & & &
\end{array}
$$

b. Den ons moeders is veul dürder.

the our mother's is much expensive-COMPAR

"Those of our mother are much more expensive."

At the surface de/den look like definite articles that precede the possessor-DP Nätjes/ons moeders. Under such an analysis, however, the possessor would be followed by an empty noun, which is generally not possible in Dutch (varieties). Thus, we would have a pattern of noun phrase-internal ellipsis. An alternative analysis would be to say that a pattern like de Nätjes in (22a) is quite similar to a pattern like Laura-s-te in (20a), the only difference being that in (22a)

\footnotetext{
${ }^{9}$ In colloquial/dialectal varieties of Dutch, one also finds the pattern negendes (nine-de-s, "ninth") instead of Standard Dutch negende. Possibly, -de-s derives from moving -de to the categorial node n, where $\mathrm{n}$ spells out as $s$.
} 
the definite pro-form de has been moved from $\mathrm{N}$ to $\mathrm{D}$, as in (23), while in (20a), the pro-form remains in situ, as represented in (21). ${ }^{10}$

$$
\text { [DP } \left.\operatorname{de}_{\mathrm{i}}\left[\mathrm{PosP} N \ddot{a} t j e s\left[\mathrm{nP} \mathrm{t}_{\mathrm{i}}\left[\sqrt{\mathrm{t}}_{\mathrm{i}}\right]\right]\right]\right]
$$

According to the analysis in (23), de starts out as a pro-form at the bottom of the extended nominal projection and moves to the highest position (D) in that same projection. If we find leftward displacement of pro-forms such as $d e$, one might raise the question whether there are also patterns in which other pronominal material starts out low and moves leftward within the noun phrase. One puzzling nominal construction that might be analyzed along those lines is given in (24):

$$
\begin{array}{lcccc}
\text { Jan } & \text { reageerde } & \text { [op } & {[z \text { 'n }} & \text { Trump's }]] . \\
\text { Jan reacted } & \text { at } & \text { his } & \text { Trump's } \\
\text { "Jan reacted in a Trump-like manner." }
\end{array}
$$

The construction in (24) is puzzling because it displays two possessor-elements in a row: $z$ 'n, which looks like a possessive pronoun, and the proper name Trump, which carries the posessormarking ' $s$. It is not so clear how to accomodate these two possessors in the extended nominal projection. Normally, there is only room for one possessor to the left of the possessum-noun: ${ }^{11}$

$$
\begin{aligned}
& \text { a. } \quad \begin{array}{l}
\text { Trump's gedrag } \\
\text { Trump's behaviour } \\
\text { "Trump's behaviour" }
\end{array} \\
& \text { b. } \quad \begin{array}{l}
z \text { 'n gedrag } \\
\text { his behaviour } \\
\text { "his behaviour" }
\end{array} \\
& \text { c. } \quad \text { *Trump's z'n gedrag } \\
& \text { d. } \quad \text { *z'n Trump's gedrag }
\end{aligned}
$$

As indicated in (24), the pattern op z'n Trumps has a manner interpretation: "in a Trump-like manner/in Trump's way". Suppose now that $z$ 'n represents the manner part of this nominal construction. Recall from our discussion of (8) that -en (i.e., /ən/) can represent "abstract"

\footnotetext{
10 As noted in Corver and van Koppen (2016), de can also undergo head movement in certain pronominal possessive constructions. For example, in Giethoorn Dutch, it is also possible to have the doubling pattern de miende besides miende (see (4b)). It is proposed that the first pattern is derived by movement of the pro-form de to $\mathrm{D}$ with spell-out of the displaced de both in the landing site position and in the base position:

(i) $\left[\mathrm{DP} \mathrm{de}_{\mathrm{i}}\left[\mathrm{PosP}\right.\right.$ mien $\left.\left.\left[\mathrm{NP} \mathrm{de}_{\mathrm{i}}\right]\right]\right] \quad$ (Giethoorn Dutch)

A similar analysis is proposed for the Standard Dutch construction de mijne, the only difference being that the trace/copy in the base position is not spelled out as de but rather as $-e$. Thus:

(ii) $\left[\right.$ DP de $_{\mathrm{i}}\left[\right.$ PosP mijn $\left.\left.\left[\mathrm{NP}-\mathrm{e}_{\mathrm{i}}\right]\right]\right] \quad$ (Standard Dutch)

${ }^{11}$ Dutch has possessor doubling patterns such as Trump z'n gedrag (Trump his behaviour, “Trump's behaviour”).

Notice, however, that 's must be absent after the possessor noun: *Trump's z'n gedrag.
} 
meanings such as time (8b), ground (8c), and way/manner (8d). I assume that $z$ ' $n$ in (24) also carries an abstract meaning, namely: "manner/way". Furthermore, I'll assume that $z$ 'n (pronounced as /zən/) can be decomposed into two elements: /z/, which I take to be a realization of the categorial node $\mathrm{n}^{\mathrm{o}}$, and /ən/, which I take to be an indefinite pro-form occupying the root position. Thus: $[n P z-[\sqrt{ }-e n]]$. The nominal pattern op $z$ 'n Trumps can now be derived as follows:

$$
\begin{aligned}
& \text { a. } \left.\left.\left.\quad\left[\mathrm{PP} \text { op [DP D [PosP Trump's [nP Z- }\left[\mathcal{V}_{-} \text {en }\right]\right]\right]\right]\right] \rightarrow \text { movement of the root to } \mathrm{n}^{\mathrm{o}} \\
& \text { b. } \left.\left.\left.\left.\quad \text { [рP op [DP D [PosP Trump's [nP Z- }-V_{-} \mathrm{en}_{\mathrm{i}}\left[\mathrm{t}_{\mathrm{i}}\right]\right]\right]\right]\right] \rightarrow \text { movement of } z \text { 'n to D } \\
& \text { c. } \quad\left[\mathrm{pP} \text { op }\left[\mathrm{DP}[\mathrm{z}-\sqrt{ }-\mathrm{en}]_{\mathrm{i}}\left[\mathrm{PosP} \text { Trump's }\left[\mathrm{nP} \mathrm{t}_{\mathrm{i}}\left[\mathrm{t}_{\mathrm{i}}\right]\right]\right]\right]\right]
\end{aligned}
$$

As indicated in (26), the derivation of op z'n Trumps involves two movement steps: First, the root $(\sqrt{ }-e n)$ raises to $\mathrm{n}^{\circ}(-z)$, and, subsequently, the complex head $z$-en (pronounced/zən/) raises to $\mathrm{D}$.

Thus far, I have tried to show that "small stuff" - specifically, elements that superficially correspond to indefinite and definite articles - can be found at the bottom of the Dutch extended nominal projection. Under a traditional NP-analysis, this means that -en and -de are pro-NPs. Furthermore, it was suggested that, under a decompositional n+Root-analysis, these elements possibly occupy the root-position of the extended nominal projection, where the categorial node n sometimes surfaces as $-s$. Of course, placing functional material (-en, - de) in a root position is unexpected in a grammar model which starts from the following assumptions (see e.g. Borer 2005): (i) a root is defined lexically by the merger of a vocabulary item that does not contain any syntactic features (i.e., it is the Vocabulary Item itself which defines a root); (ii) there is a strict division of labor between the functional domain and the lexical domain; that is, functional vocaluary items always and only spell out functional terminal nodes, whereas lexical vocabulary items always and only spell out root terminal nodes. As an alternative approach (de Belder 2011), however, it has been proposed (i) that a root is defined structurally if it is a terminal node which does not contain any category-specific syntactic features (see Halle and Marantz 1993; Harley and Noyer 1999), and (ii) that there is not a strict division of labor between the lexical domain and the functional domain, in the sense that functional vocabulary items can sometimes realize root terminal nodes. De Belder (2011: 41-44), for example, gives the following illustrations of the use of functional vocabulary items as roots:

$$
\begin{array}{llll}
\text { a. De studenten } & \text { jij-en } & \text { onderling. } \\
\text { the } & \text { students } & \text { you-INF } & \text { mutually }
\end{array}
$$

"The students are on a first-name basis with one another."

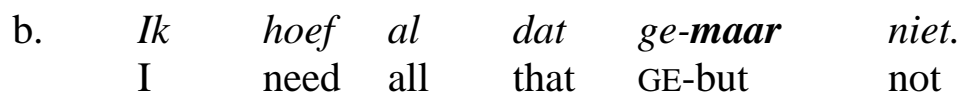
"I don't like those constant objections."

Similar illustrations with $d e$ and $-e n / ' n$ are given in (28):

a. Tweede-taalleerders van het Nederlands de-en vaak.
second-language-learners of the
"Second language learners of Dutch often use de (before nouns)."




b. Snap jij dat ge-'n bij subjecten in existentiële
understand you that GE-a with subjects in existential
constructies?
constructions
"Do you understand this constant use of 'a' with subjects in existential
constructions?"

For reasons of space, I will limit myself to the above-mentioned brief remarks about the appearance of functional material in root terminal positions. I hope to come back to this issue in future research.

Summarizing: in this article, I argued that linguists should be concerned about the small linguistic elements. In other words: "Do sweat the small linguistic stuff!". In line with the Categorial identity hypothesis - i.e., the idea that the layers in an extended projection are of the same categorial type - I tried to show that small stuff - specifically, functional material corresponding to definite and indefinite articles - can be found at the bottom of the extended nominal projection. The evidence for "small linguistic stuff at the bottom" came from nominal constructions that, to my knowledge, have not received much attention in the syntactic literature so far. ${ }^{12}$ In this article, I have only touched upon certain morphosyntactic aspects of these constructions, and it goes without saying that each of these constructions deserves a more indepth analysis. Nevertheless, I hope to have shown that patterns such as mienen, miende, gekkens, overigens, hetzelfde, zesde, Lauraste, and op z'n Trumps display what Feynman called "beauty at smaller dimensions".

\section{References}

Abney, S. 1987. The English noun phrase in its sentential aspect. Doctoral dissertation. Cambridge, MA: MIT.

de Belder, M. 2009. On the occurrence of titles. TIN-dag talk, Utrecht.

de Belder, M. 2011. Roots and affixes. Eliminating lexical categories from syntax. Doctoral dissertation: Utrecht University and HU Brussels.

\footnotetext{
${ }^{12}$ We expect to find "low high stuff" in the adjectival, adpositional and clausal domain. For the adjectival domain,

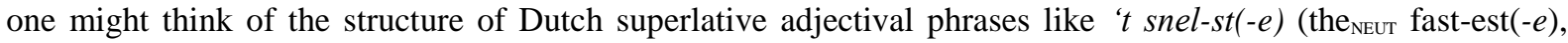
"fastest"), where the Dutch superlative element $-s t(-e)$ possibly has the compositional structure $-s+-t(e)$, analogously to tselofste and negenste in (19). Thus: [het [snel $[x P-s[\sqrt{ }-t(e)]]]$, where $t(e)$ could be analyzed as a pro-form and $-s$ as a realization of a categorial head. In a language like English, the word so occurs as a "high" functional degree word, as in so tall (that he couldn't enter the room), but also as a low pro-predicate, as in too much so (see Corver 1997). In the left periphery of Dutch locative PPs, one can find the R-pronoun er "there" as in er achter (there behind, "behind it"); see van Riemsdijk 1978. The form er is also attested on locative expressions like daarginder (there-yonder "over there/yonder"), which exists next to daarginds, which features $s$ at the end. Possibly, this er at the end (bottom?) of the construction relates to the R-pronoun er, which occurs in the left periphery of extended adpositional phrases. As for the clausal domain, the well-known observation that the property of finiteness is associated both with the C-position (e.g. the subordinator dat "that") and with the verb comes to mind (den Besten 1983). Also the fact that the "nominal forms" of verbs display -en (pronounced /on/, just like the indefinite article) or $-t /-d$ after the root is quite intriguing, since these forms are, at least superficially,

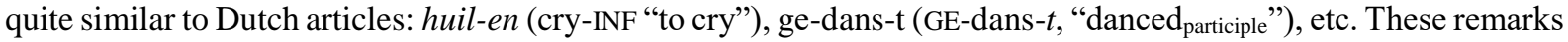
are, obviously, highly speculative. More in-depth research is needed for finding out whether the appearance of "high" functional stuff in low positions ("the bottom of the tree") is a cross-categorial phenomenon.
} 
den Besten, H. 1983. On the interaction of root transformations and lexical deletive rules. In W. Abraham (ed.). On the formal syntax of the Westgermania. Papers from the 3rd Groningen Grammar Talks, January 1981. Amsterdam: John Benjamins. pp. 47-131.

Bennis, H., N. Corver and M. den Dikken 1998. Predication in nominal phrases. The Journal of Comparative Germanic Linguistics, 1: 85-117.

de Boer, B. 1950. Studie over het dialect van Hindeloopen. Assen: Van Gorcum \& Comp. N.V. de Bont, A.P. 1958. Dialekt van Kempenland. Meer in het bijzonder d'Oerse taol. Deel 1. Klank- en vormleer en enige syntactische bijzonderheden. Assen: Van Gorcum \& Comp. N.V.

Borer, H. 2005. Structuring sense. Volume 1: In name only. Oxford: Oxford University Press.

Carlson, R. 1997. Don't sweat the small stuff . . and it's all small stuff. New York: Hyperion.

Chomsky, N. 1986. Barriers. Cambridge, MA: MIT Press.

Corver, N. 1997. Much-support as a last resort. Linguistic Inquiry, 28: 119-164.

Corver, N. 2013. Lexical categories and (extended) projection. In M. den Dikken (ed.). Handbook of generative syntax. Cambridge: Cambridge University Press. pp. 353-424.

Corver, N. (to appear). Adverbial $-s$ : so awks but so natural! In D. Lightfoot and J. Havenhill (eds). Variable properties in language: Their nature and acquisition. Washington, DC: Georgetown University Press.

Corver, N. and M. van Koppen 2010. Ellipsis in Dutch possessive noun phrases: a microcomparative approach. Journal of Comparative Germanic Linguistics, 13: 99-140.

Corver, N. and M. van Koppen 2016. Pronominalization and variation in Dutch demonstrative expressions. Unpublished ms: Utrecht University.

Emonds, J. 1978. The verbal complex V'-V in French. Linguistic Inquiry, 9: 151-175.

Emonds, J. 1985. A unified theory of syntactic categories. Dordrecht: Foris.

Feynman, R. 2007. There is plenty of room at the bottom. In R. Feynman (ed.) The pleasure of finding things out. London: Penguin. pp. 117-140.

Grimshaw, J. 1991. Extended projection. Unpublished manuscript, Brandeis university, Waltham, MA. [Published in Grimshaw (2005). pp. 1-73.]

Grimshaw, J. 2005. Words and structure. Stanford, CA: CSLI Publications.

Halle, M. and A. Marantz 1993. Distributed Morphology and the pieces of inflection. In K. Hale and S.-J. Keyser (eds). The view from building 20. Cambridge, MA: MIT Press. pp. 111176. 
Harley, H. and R. Noyer 1999. State-of-the-Article: Distributed Morphology. Glot International, 4(4): 3-9.

van Kampen, J. and N. Corver 2006. Diversity of possessor marking in Dutch child language and Dutch dialects. In M. Vliegen (ed.). Variation in Sprachtheorie und Spracherwerb. Proceedings of the 39th Linguistic Colloquium 2004. Berlin: Lang. pp. 385-398.

ter Laan, K. 1953. Proeve van een Groninger spraakkunst. Winschoten: Van der Veen.

Longobardi, G. 1994. Reference and proper names: A theory of N-movement in syntax and Logical Form. Linguistic Inquiry, 25: 609-665.

Marantz, A. 1997. No escape from syntax: Don't try morphological analysis in the privacy of your own lexicon. University of Pennsylvania Working Papers in Linguistics, 4: 201-225.

Pauwels, J.L. 1958. Het dialect van Aarschot en omstreken, Volume 1. Belgisch Interuniversitair Centrum voor Neerlandistiek.

Pesetsky, D. 2013. Russian case morphology and the syntactic categories. Cambridge, MA: MIT Press.

Pollock, J-Y. 1989. Verb movement, Universal Grammar and the structure of IP. Linguistic Inquiry, 20: 365-424.

Pretorius, E. 2017. Spelling out P. A unified syntax of Afrikaans adpositons and V-particles. Doctoral dissertation. Utrecht University and Stellenbosch University.

van Riemsdijk, H. 1978. A case study in syntactic markedness: the binding nature of prepositional phrases. Dordrecht: Foris.

van Riemsdijk, H. 1998. Categorial feature magnetism: The endocentricity and distribution of projections. Journal of Comparative Germanic Linguistics, 2: 1-48.

Ritter, E. 1988. A head-movement approach to construct state noun phrases. Linguistics, 26: 909-929.

Royen, G. 1947-1954. Buigingsverschijnselen in het Nederlands. (4 volumes) Amsterdam: Noord- Hollandsche Uitgeversmaatschappij.

Talmy, L. 2000. Toward a cognitive semantics: concept structuring systems. Cambridge, MA: MIT Press. 